\title{
Pemanfaatan Sari Pati Buah Sukun (Artocarpus altilis) Sebagai Alternatif Media Pertumbuhan Aspergillus niger
}

\author{
TUTY YUNIARTY ${ }^{1}$, ANITA ROSANTY ${ }^{1}$ \\ ${ }^{1}$ Jurusan Analis Kesehatan, Poltekkes Kemenkes Kendari \\ Jl. Jend. A. H. Nasution No. 614 Anduonohu, Kendari, Sulawesi Tenggara. 93127 \\ Email: thutyyuniarty@yahoo.co.id
}

Received 12 December 2017; Received in revised form 11 January 2018;

Accepted 2 February 2018; Available online 3 February 2018

\begin{abstract}
Aspergillus niger is a fungi family Trichocomaceae that form filaments, mycelia, and conidiospore can produce citric acid and does not contain mycotoxins. The media are used as a medium for growth of the fungi Aspergillus niger is SDA (Saboroud Dextrose Agar) which commercially available. This study aims to determine the possible use of based starch breadfruit as alternate media for Aspergillus niger. Inoculation of the fungi Aspergillus niger was conducted using a single dot (one point). The results found macroscopic colonies dark brown to black, round and microscopic hyphae and spores use $\mathrm{KOH} 10 \%$ solution that is suggesting that Aspergillus niger can grow in the growth media made from starch breadfruit.
\end{abstract}

Keywords: Aspergillus niger, breadfruit, media

\section{INTISARI}

Aspergillus niger merupakan jamur Trichocomaceae yang membentuk filamen, miselia dan konidiospora yang dapat menghasilkan asam sitrat dan tidak mengandung mikotoksin. Media yang digunakan sebagai media untuk pertumbuhan jamur Aspergillus niger adalah SDA (Saboroud Dextrose Agar) yang tersedia secara komersial. Penelitian ini bertujuan untuk mengetahui kemungkinan penggunaan sari pati buah sukun sebagai media alternatif untuk Aspergillus niger. Inokulasi jamur Aspergillus niger dilakukan dengan menggunakan single dot (satu titik). Hasil penelitian menemukan koloni makroskopik cokelat tua sampai hitam, bulat dan hifa mikroskopis dan spora menggunakan larutan $\mathrm{KOH} 10 \%$ yang menunjukkan bahwa jamur Aspergillus niger dapat tumbuh di media pertumbuhan berbahan dasar sari pati buah sukun.

Kata kunci: Aspergillus niger, media, sukun

\section{PENDAHULUAN}

Aspergilosis adalah suatu spektrum penyakit jamur yang disebabkan oleh sejumlah spesies Aspergillus dapat mengenai kulit, kuku, dan organ-organ dalam terutama paru dan otak. Aspergillus sp. merupakan salah satu jamur saprofit yang terdapat di alam bebas, menyebar melalui udara terutama di daerah tropik dengan kelembaban yang tinggi. Pada kasus tertentu banyak Aspergillus sp. yang bersifat patogen dan menyebabkan penyakit pada manusia seperti A. fumigatus, A. flavus, $A$ niger dan A. terreus (Jawetz, 2012).
Aspergillus niger merupakan fungi yang berfilamen, mempunyai hifa bersepta dan dapat ditemukan di alam. Jamur ini biasanya diisolasi dari tanah, sisa tumbuhan, dan udara di dalam ruangan. Pada media SDA (Saboroud Dextrose Agar), koloni berwarna putih atau kuning dengan lapisan konidiospora tebal berwarna cokelat gelap sampai hitam. Kepala konidia berwarna hitam, bulat, cenderung memisah menjadi bagian-bagian yang lebih longgar dengan bertambahnya umur. Konidiospora memiliki dinding yang halus, hialin dan berwarna cokelat. Dalam metabolismenya Aspergillus niger dapat 
menghasilkan asam sitrat yang banyak digunakan pada berbagai makanan dan minuman ataupun pengawet dan peningkat cita rasa, selain itu karena tidak mengandung mikotoksin maka jamur ini digunakan dalam berbagai fermentasi (Kusumaningtyas, 2007).

Di laboratorium mikrobiologi, fungi patogen didiagnosis dengan beberapa pemeriksaan yaitu pemeriksaan sediaan langsung, pembiakan, tes imunologi, biopsi jaringan dan pemeriksaan dengan sinar Wood. Pembiakan atau kultur jamur pada umumnya menggunakan perbenihan SDA (Saboroud Dextrose Agar), PDA (Potato Dextrose Agar), CMA (Corn Meal Agar)(Mutiawati, 2016).

Media yang digunakan sebagai media pertumbuhan fungi Aspergillus sp. di laboratorium adalah SDA (Saboroud Dextrose Agar) dengan penambahan antibiotik kloramfenikol yang berfungsi untuk mencegah pertumbuhan bakteri. Komposisi dari media SDA (Saboroud Dextrose Agar) adalah 5 gram peptone sebagai sumber nitrogen, 40 gram dextrose sebagai sumber karbohidrat, 15 gram agar-agar sebagai bahan tambahan yang berfungsi untuk pemadat dan antibiotik kloramfenikol yang berfungsi untuk mencegah pertumbuhan bakteri (Getas dkk., 2014).

Pembuatan media pertumbuhan Aspergillus sp. di laboratorium umumnya menggunakan media dalam bentuk formula dan tersedia secara komersial. Untuk mengurangi ketergantungan kepada penyelia SDA, peneliti merasa perlu menggunakan media alternatif dari bahan yang komposisinya mengandung nutrisi yang dibutuhkan untuk pertumbuhan jamur (Manfaati, 2011).

Tanaman sukun merupakan tanaman yang menghasilkan buah dengan kandungan gizi tinggi, dan potensial dijadikan sebagai bahan makanan pokok alternatif pengganti beras (Adinugraha dan Kartikawati, 2012). Komposisi gizi dari sukun adalah mengandung karbohidrat $25 \%$, protein $1,5 \%$, dan lemak $0,3 \%$ dari berat buah sukun. Selain itu buah sukun juga banyak mengandung unsur-unsur mineral serta vitamin B1, B2 dan vitamin C yang sangat dibutuhkan oleh tubuh. Unsurunsur mineral yang terkandung dalam buah sukun antara lain adalah $\mathrm{Ca}$ (Kalsium), $\mathrm{P}$
(Fosfor) dan $\mathrm{Fe}$ (Zat besi). Kandungan air dalam buah sukun cukup tinggi yaitu sekitar $69,3 \%$ serta proses penanaman dan pengolahan jauh lebih mudah dibandingkan padi (Widowati, 2016; Hartanti dkk., 2012; Suparman dan Ahmad, 2015).

Berdasarkan hal ini perlu dilakukan penelitian mengenai pemanfaatan sari pati buah sukun (Artocarpus altilis) sebagai media alternatif pertumbuhan Aspergillus niger dengan parameter pertumbuhan koloni dan hifa.

\section{METODE}

Persiapan. Sampel yang digunakan adalah sari pati buah sukun yang telah bersih dan kering sebanyak 12,5 gram. Desain penelitian yang digunakan adalah perbandingan kelompok statis (Static Group Comparison) yaitu membandingkan pertumbuhan Aspergillus niger pada alternatif media padat berbahan dasar sari pati buah sukun sebagai kelompok eksperimen dan pertumbuhan A. niger pada media Sabouroud Dextrose Agar (SDA) sebagai kelompok kontrol (Soekidjo, 2010).

Pengujian. Alat yang digunakan disterilisasi dengan menggunakan oven pada suhu $180^{\circ} \mathrm{C}$ selama $1 \mathrm{jam}$. Media pertumbuhan SDA dibuat dengan cara menimbang media SDA sebanyak 19,5 gram, dilarutkan dengan akuades sebanyak $300 \mathrm{ml}$ sampai homogen. Pengukuran $\mathrm{pH}$ media yaitu 5,6 $\pm 0,2$ disterilisasi menggunakan autoclave pada suhu $121^{\circ} \mathrm{C}$ selama 15 menit, pada tekanan $1 \mathrm{~atm}$, kemudian dituang pada cawan petri secara aseptik, setelah dingin jamur $A$. niger dari PT Biofarma diinokulasi dengan penambahan antibiotik kloramfenikol metode single dot pada media SDA pada suhu $28^{\circ} \mathrm{C}$ selama $3 \mathrm{x}$ 24 jam.

Pembuatan sari pati buah sukun dilakukan dengan cara buah sukun dihancurkan menggunakan blender, ditambahkan akuades, disaring menggunakan kain kasa sehingga tidak ada lagi kotoran atau ampas sukun dalam sari buah sukun, didiamkan selama satu malam untuk mendapatkan endapan (pati) kemudian filtrat dibuang dan endapan (pati) dikeringkan. 
Penimbangan sari pati buah sukun dilakukan dengan mengikuti aturan jumlah penimbangan pada media SDA sebagai kontrol yaitu 65 gram dalam $1000 \mathrm{ml}$. Sari pati buah sukun yang telah bersih dan kering ditimbang sebanyak 12,5 gram, dilarutkan dengan akuades sebanyak $300 \mathrm{ml}$ kemudian ditambahkan agar-agar batang sebanyak 7 gram sebagai pemadat, kemudian disterilisasi menggunakan autoclave pada suhu $121^{\circ} \mathrm{C}$ selama 15 menit, pada tekanan $1 \mathrm{~atm}$, kemudian dituang pada cawan petri secara aseptik, setelah dingin jamur A. niger dari PT Biofarma diinokulasi dengan penambahan antibiotik kloramfenikol metode single dot pada media sari pati buah sukun pada suhu $28^{\circ} \mathrm{C}$ selama $3 \times 24$ jam.

Pengamatan. Aspergillus niger diamati secara makroskopik dengan melihat pertumbuhan dan secara mikroskopik dengan warna koloni. Satu ose koloni A. niger diletakkan pada permukaan kaca objek dan ditambahkan larutan $\mathrm{KOH} 10 \%$, kemudian diamati spora dan hifa di bawah mikroskop dengan pembesaran 10x. Data yang dikumpulkan adalah data primer hasil pembuatan media sari pati buah sukun dan hasil pengamatan koloni Aspergillus niger secara makroskopik dan mikroskopik.

\section{HASIL}

Berdasarkan pengamatan pertumbuhan Aspergillus niger secara makroskopik terhadap media Sabouraud Dextrose Agar (SDA) dan media padat berbahan dasar sari pati buah sukun diperoleh hasil sebagaimana tercantum dalam tabel 1 .

Tabel 1. Hasil pengamatan Aspergillus niger pada media Sabouraud Dextrose Agar (SDA) dan media sari pati buah sukun.

\begin{tabular}{clcc}
\hline No. & \multicolumn{1}{c}{ Media } & Hasil Pengamatan Makroskopik & Kesimpulan \\
\hline $\mathbf{1}$ & $\begin{array}{l}\text { Sabouraud Dextrose } \\
\text { Agar (SDA) }\end{array}$ & $\begin{array}{c}\text { Koloni Berwarna cokelat tua, hingga } \\
\text { hitam, berfilamen }\end{array}$ & $\begin{array}{c}\text { terdapat hifa } \\
\text { Aspergillus niger } \text { dan } \\
\text { spora }\end{array}$ \\
\hline $\mathbf{2}$ & $\begin{array}{l}\text { Media sari pati buah } \\
\text { sukun }\end{array}$ & $\begin{array}{c}\text { Koloni Berwarna cokelat tua, hingga } \\
\text { hitam, berfilamen }\end{array}$ & $\begin{array}{c}\text { terdapat hifa } \\
\text { Aspergillus niger } \text { dan } \\
\text { spora }\end{array}$ \\
\hline
\end{tabular}

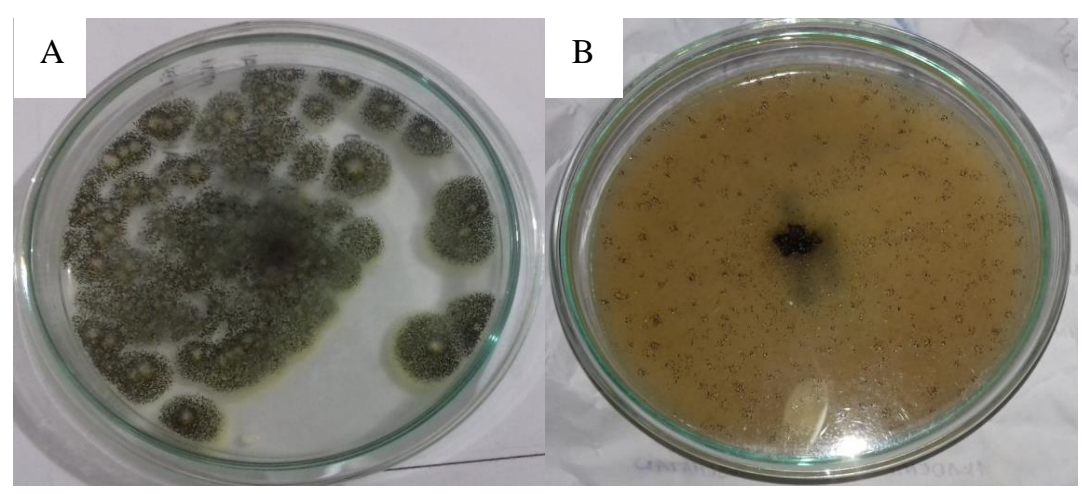

Gambar 1. Hasil Makroskopik pertumbuhan Aspergillus niger (A: Media Sabouraud Dextrose Agar; B: Media sari pati buah sukun)

Dari gambar 1 dan gambar 2 menunjukkan bahwa pada hasil pengamatan secara makroskopik terhadap media Sabouraud Dextrose Agar (SDA) dan media sari pati buah sukun yaitu koloni berwarna cokelat tua hingga hitam dan berfilamen. Sedangkan pada hasil pengamatan secara mikroskopik terhadap media Sabouraud Dextrose Agar (SDA) dan media dasar sari pati buah sukun yaitu adanya hifa dan spora. Hasil pengamatan tersebut merupakan ciri-ciri pertumbuhan jamur Aspergillus niger. 


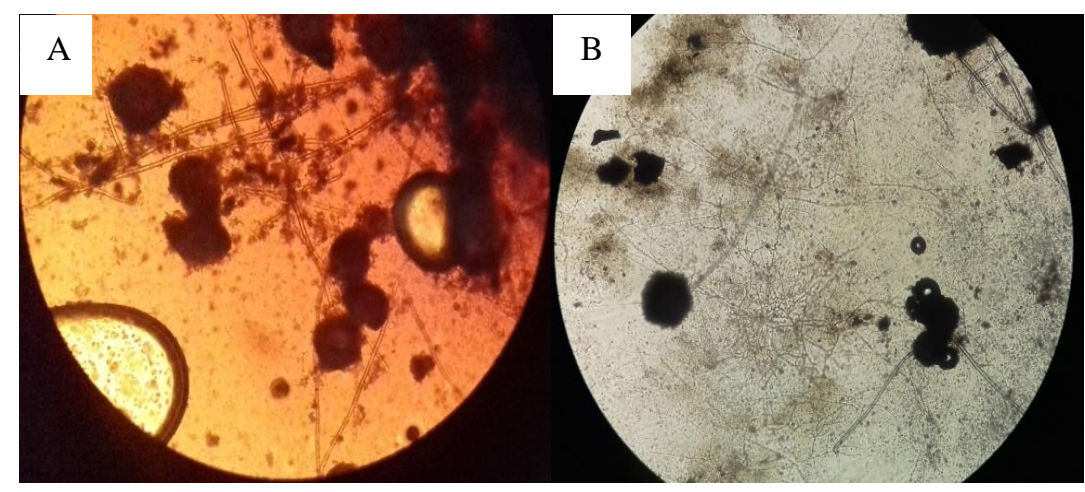

Gambar 2. Hasil Mikroskopik pertumbuhan Aspergillus niger

(A: Hifa dan koloni media Sabouraud Dextrose Agar; B: Hifa dan koloni media sari pati buah sukun)

\section{PEMBAHASAN}

Penelitian yang dilakukan bersifat quasi experimental design (penelitian semu), menggunakan kelompok kontrol media Sabouraud Dextrose Agar (SDA) dan kelompok eksperimen media sari pati buah sukun dan menunjukkan hasil yang sama secara makroskopik dan mikroskopik. Untuk kelangsungan hidup fungi Aspergillus niger memerlukan protein sebagai sumber nutrisi, karbohidrat sebagai sumber energi, serta mineral dan vitamin sebagai bahan untuk pertumbuhan. Selain itu fungi A. niger juga memerlukan kondisi habitat yang mempunyai kelembaban yang tinggi dan ketersediaan oksigen yang cukup (Roosheroe dkk., 2014)

Berdasarkan penelitian yang dilakukan Susilowati dan Listyawati (2001), hasil pengukuran koloni A. niger dan A. flavus yang tumbuh pada media SDA dan pada modifikasi media taoge diperoleh hasil pada beberapa perlakuan yang dilakukan berada di bawah nilai rata-rata diameter koloni Aspergillus sp. pada media SDA. A. niger pada media SDA tumbuh optimum selama 3 hari pada suhu 25$30^{\circ} \mathrm{C}$ dengan kurva pertumbuhan yang sangat cepat karena tidak memerlukan waktu adaptasi dengan media pertumbuhannya yang cukup lama (Igbinosa et al., 2009). Pada media berbahan dasar sari pati buah sukun $A$. niger menggunakan waktu 12 - 24 jam sebagai fase adaptasi (fase lag). Dalam fase adaptasi ini, jamur dalam tahap penyesuaian terhadap lingkungan baru. Kondisi ini terjadi karena adanya perubahan media serta lingkungannya dari media sari pati buah sukun.
Mikroorganisme yang dipindahkan ke dalam suatu medium mula-mula akan mengalami fase adaptasi, melakukan penyesuaian sel-sel dengan lingkungan pembentukan enzim-enzim untuk mengurai substrat. Setelah fase adaptasi pada hari ke-4, jamur mengalami fase akselerasi, fase lag menjadi fase aktif, jamur Aspergillus niger membelah dengan cepat dan akan mengalami pertumbuhan terus menerus ke fase eksponensial yang merupakan fase perbanyakan jumlah sel. Aktivitas sel akan meningkat dan dipengaruhi oleh medium tempat tumbuhnya seperti kandungan nutrien dan kondisi lingkungan termasuk suhu dan kelembaban udara (Maryanty dkk., 2010). Hal ini membuktikan bahwa syarat-syarat pertumbuhan mikroorganisme khususnya $A$. niger seperti konsentrasi substrat baik protein, karbohidrat, mineral dan vitamin serta $\mathrm{pH}$ pada modifikasi media sari pati buah sukun memenuhi untuk pertumbuhan A. niger.

Hasil pengamatan makroskopik diperoleh morfologi koloni A. niger berwarna cokelat tua hingga hitam dan berfilamen, sedangkan dari pengamatan mikroskopik diperoleh hasil tampak hifa bercabang, bersegmen, membentuk sudut tajam di atas sel kaki atau hifa yang tidak bersegmen. Terbentuk pula konidiofora yang pada ujungnya terbentuk vesikel dan pada permukaannya membentuk sterigmata yang pada ujungnya membentuk mikrokonidia. Untuk keperluan hidup mikroorganisme membutuhkan bahan-bahan organik dan anorganik dari lingkungannya, salah satunya dari media tumbuh. Media 
tumbuh yang ditambahkan agar-agar berfungsi sebagai pemadat serta ditambahkan antibiotik yang berfungsi untuk menghambat pertumbuhan mikroba non target/kontaminan. Kedua bahan tambahan ini mampu menjadi media tumbuh yang baik bagi A. niger.

\section{KESIMPULAN}

Aspergillus niger mampu tumbuh pada media sari pati buah sukun. Media sari pati buah sukun tersebut dapat digunakan sebagai media alternatif pertumbuhan Aspergillus niger.

\section{UCAPAN TERIMA KASIH}

Ucapan terima kasih disampaikan kepada Direktur Poltekkes Kemenkes Kendari dan Ketua Jurusan Analis Kesehatan Poltekkes Kendari atas izin dan dukungan yang diberikan untuk melaksanakan penelitian ini.

\section{DAFTAR PUSTAKA}

Adinugraha HA dan Kartikawati NK. 2012. Variasi Morfologi dan Kandungan Gizi Buah Sukun. Wana Benih. vol 13(2): 99106.

Getas IW, Wiadnya IBR, Waguriani LA. Pengaruh Penambahan Glukosa dan Waktu Inkubasi Pada Media SDA (Sabouraud Dextrose Agar) Terhadap Pertumbuhan Jamur Candida albicans. Media Bina Ilmiah. vol 8(1): 51-56.

Hartanti FD, Amanto BS, Rahadian DAM. 2012. Kajian Karakteristik Fisikokimia Tepung Sukun (Artocarpus communis) Termodifikasi Dengan Variasi Konsentrasi dan Lama Perendaman Asam Laktat. Jurnal Teknosains Pangan. vol 2(4): 54-61.

Igbinosa OO, Igbinosa E, Aiyegoro OA. 2009. Antimicrobial activity and phytochemical screening of stem bark extracts from Jatropha curcas (Linn). African journal of pharmacy and pharmacology. vol 3(2): 58-62.
Jawetz M and Adelberg's. 2012. Medical Microbiology. $26^{\text {th }}$ ed. New York: Mc. Graw Hill. pp. 149.

Kusumaningtyas E. 2014. Viabilitas dan Morfologi Aspergillus fumigatus pada Penyimpanan dengan Kertas Saring dan Agar dalam Air Suling. JITV. vol 19(3): 892-896.

Manfaati R. 2011. Pengaruh Komposisi Media Fermentasi Terhadap Produksi Asam Sitrat oleh Aspergillus niger. Jurnal Fluida. vol 7(1): 23-27.

Maryanty Y, Pristianti H, and Ruliawati P. 2010. Produksi Crude Lipase Dari Aspergillus niger Pada Substrat Ongok Menggunakan Metode Fermentasi Fasa Padat. Seminar Rekayasa Kimia Dan Proses, 4-5 Agustus 2010. Semarang: Teknik Kimia Universitas Diponegoro.

Mutiawati VK. 2016. Pemeriksaan Mikrobiologi Pada Candida albicans. Jurnal Kedokteran Syiah Kuala. vol 16(1): 53-63.

Roosheroe IG, Sjamsuridzal W, Oetari A. 2014. Mikologi Dasar dan Terapan. Edisi Revisi. Jakarta: Pustaka Obor Indonesia.

Suparman dan Ahmad Z. 2015. Pemetaan Awal Ditribusi Populasi Tanaman Sukun (Artocarpus altilis (Parkinson) Fosberg 1941) di Pulau Ternate. Biogenesis. vol 3(2): 132-137.

Soekidjo N. 2010. Metodologi penelitian kesehatan. Jakarta: Rineka Cipta. hal: 505.

Susilowati A dan Listyawati S. 2001. Keanekaragaman Jenis Mikroorganisme Sumber Kontaminasi Kultur In vitro di Sub-Lab. Biologi Laboratorium MIPA Pusat UNS. Biodiversitas. vol 2(1): 110114.

Widowati S. 2016. Prospek Sukun (Artocarpus communis) sebagai Pangan Sumber Karbohidrat dalam Mendukung Diversifikasi Konsumsi Pangan. Jurnal Pangan. vol 18(4): 67-75. 